\title{
Long-term vitamin status and dietary intake of healthy elderly subjects
}

\section{Riboflavin}

\author{
By INGRID H. E. RUTISHAUSER,* C. J. BATES, ALISON A. PAUL \\ AND ALISON E. BLACK \\ Dunn Nutrition Unit, University of Cambridge and Medical Research Council,
Cambridge
}

\author{
AND A. R. MANDAL AND B. K. PATNAIK† \\ Department of Geriatric Medicine, Sunderland General Hospital, Chester Road, \\ Sunderland
}

(Received I5 November 1978 - Accepted 12 February 1979)

\begin{abstract}
I. Long-term clinical and biochemical riboflavin status and dietary intake of riboflavin were monitored for 18 months in a group of twenty-three relatively-healthy elderly subjects living at home in the north of England.

2. Both dietary intake and biochemical status, as measured by the activation coefficient (stimulated: basal activity) of $\mathrm{NAD}(\mathrm{P}) \mathrm{H}_{2}$ : glutathione oxidoreductase $\left(E C_{1} .6 .4 .2\right)$, remained fairly constant for each individual and for most subjects the usual intake and biochemical status were characterized quite accurately by a single week's intake dietary record and a single measurement of the activation coefficient.

3. The expected relationship between biochemical status and dietary intake was present, but not strongly evident. There was a significant within-subject correlation between $\alpha$ values and the immediately preceding dietary intake; however the between-subject correlation between $\alpha$ values and dietary intake approached zero if the two subjects receiving long-term riboflavin supplements were omitted. Over the limited range of intakes observed in unsupplemented subjects, non-dietary factors evidently obscure the relationship.

4. Although eight subjects had average values above $I \cdot 2$ for the activation coefficient, no excessively high values were observed, and no subject showed any clear-cut clinical deficiency symptoms.
\end{abstract}

Attention has been focused in recent years on the nutritional status of the elderly, and in particular on the incidence of low blood levels of a number of vitamins in comparison with those of younger age-groups in the population (Brin et al. 1964; Griffiths et al. 1967; Department of Heaiiin and Social Security (DHSS, 1972). It is not known whether this is a normal concomitant of the ageing process or primarily a reflection of the increased incidence of disease and disability or of changes in nutrient intake in this age-group, nor whether it has any functional significance.

Exton-Smith \& Stanton (1965) in a cross-sectional study of women aged 70-80 years living at home found a decline in the intake of nutrients with increasing age. This, they suggested, could have been due to physiological ageing, to increasing incidence of disease, to differing life-long dietary patterns or to the failure of certain individuals to reach extreme old age. From a follow-up study of the younger women, some 6.5 years later, however, Stanton \& Exton-Smith (1970) concluded that falls in intakes during the eighth decade were the consequence of increasing physical and mental disabilities. In discussing the relationship between diet and vitamin status in the elderly, therefore, it seems important to

\footnotetext{
* Present address: Deakin University, Geelong Victoria, PO Box 125, Belmont 3216, Victoria, Australia.

$\uparrow$ Present address: Grantham and Kesteven General Hospital, Manthorpe Road, Grantham, Lincolnshire NG31 8DG.
} 
distinguish between those suffering from disease or disability and those who remain essentially healthy for their age.

The DHSS in two national surveys of the elderly in 1967-8 (DHSS, 1972) and in 1972-3 (DHSS, 1979) found little evidence of overt clinical malnutrition. The dietary and biochemical findings, however, suggested that a relatively large number of individuals might be on the borderline of adequate nutritional status, in particular for riboflavin and vitamin C. It is not clear, however, whether single biochemical measurements provide a reliable indication of long-term vitamin status, or whether short-term dietary studies are adequate for measuring an individuals' average dietary intake.

The present study of vitamin status in a group of relatively-healthy people living at home, was designed to investigate three questions: $(a)$ how constant are dietary intake and biochemical status for each individual over an extended period; $(b)$ how closely do biochemical indices correlate with recent and long-term dietary intake; $(c)$ what clinical and functional significance can be attached to low tissue vitamin levels?

The present paper describes the subjects and methodology of the study, and discusses the relationship between the dietary and biochemical indices of riboflavin status. The second paper deals with vitamin $\mathrm{C}$, (ascorbic acid and dehydroascorbic acid) and the result of a period of supplementation with this vitamin (Bates et al. 1979). Aspects of vitamin D and folic acid status will appear elsewhere.

\section{METHODS}

Twenty-three individuals living in Sunderland, twelve male and eleven female, aged 72-86 years at the start of the study, were followed for 60 weeks. Each subject attended the geriatric out-patient department of the local hospital on enrolment and on five subsequent occasions at I2-weekly intervals; at each visit they had a full clinical examination, and blood samples were taken for biochemical estimations. Food intake was monitored continuously throughout the study by qualitative and quantitative records; two field workers stationed in Sunderland were responsible for collecting all the dietary information. A trained nurse visited the subjects regularly to monitor intercurrent illness, medication and changes in social circumstances; she also provided the vital link with the survey team, and her presence was, without doubt, paramount in maintaining the co-operation of the subjects.

\section{Subjects}

The subjects were selected from these previously studied by the DHSS in 1967-8 and followed up in 1972-3 (DHSS, 1972; DHSS, 1979). Thus background information on the health and vitamin status of individuals was available. Sunderland was chosen as the area for the study, since it was in this area, of the six included in the DHSS surveys, that the greatest proportion of individuals had low vitamin $\mathrm{C}$ or riboflavin status.

Of the original 199 individuals in $1967-8$, II 2 were still alive in July 1975. Of these, thirty-four had 'better-than-average' health for their age in 1972-3 and were considered eligible for the present study. Those with the highest and the lowest biochemical indices of vitamin $\mathrm{C}$ or riboflavin status or both in $1972-3$ were approached first; twenty-four were enrolled over the period July-August 1975, of whom four dropped out during the first 3 months and were replaced during September-November 1975. One further subject died after the first 3 months and is not included in the analysis; the remaining twenty-three participated throughout. Table I gives background information about each subject, individual values as well as group means are given both here and in subsequent tables, because a major aim of the study was to assess longitudinal variation within individuals. 
Table I. Details of subjects participating in the study

\begin{tabular}{|c|c|c|c|c|c|c|c|}
\hline $\begin{array}{l}\text { Subject no. } \\
\text { Men }\end{array}$ & $\underset{\text { (years) }}{\text { Age }}$ & Smokers & $\begin{array}{r}\mathrm{Wt} \\
(\mathrm{kg})\end{array}$ & $\begin{array}{l}\text { Height } \\
\text { (m) }\end{array}$ & $\begin{array}{c}\text { Marital } \\
\text { status }\end{array}$ & $\begin{array}{l}\text { Household } \\
\text { composition }\end{array}$ & $\begin{array}{l}\text { Social } \\
\text { class* }\end{array}$ \\
\hline I & 80 & - & 74.9 & $\mathrm{I} \cdot 74 \mathrm{I}$ & W & A & III A \\
\hline 2 & 84 & C & $52 \cdot 2$ & $\mathrm{I} \cdot 54 \mathrm{I}$ & $\mathbf{M}$ & Sp & IV \\
\hline 3 & 78 & $\mathbf{P}$ & $59 \cdot 0$ & I. 619 & W & $\mathbf{R}$ & II \\
\hline 4 & 77 & - & $74 \cdot 6$ & 1.598 & M & Sp & II \\
\hline 5 & 75 & C & $56 \cdot 7$ & $I \cdot 560$ & $\mathbf{M}$ & $\mathrm{sp}$ & III \\
\hline 6 & 76 & - & $75 \cdot 3$ & 1.678 & W & A & III A \\
\hline 7 & 72 & - & $88 \cdot 4$ & $I \cdot 717$ & $\mathbf{M}$ & Sp & III \\
\hline 8 & 74 & C & $78 \cdot 4$ & $1 \cdot 690$ & M & $\mathrm{Sp}$ & III \\
\hline 9 & 78 & C & 60.0 & $\mathrm{I} \cdot 58 \mathrm{I}$ & $\mathrm{S}$ & $\mathbf{R}$ & III \\
\hline 10 & 77 & $\mathrm{C}$ & $55 \cdot 3$ & $1 \cdot 660$ & $\mathbf{M}$ & SpR & V \\
\hline I I & 75 & $\mathrm{C}$ & $47 \cdot 9$ & $1 \cdot 547$ & $\mathbf{M}$ & $\mathrm{SpR}$ & V \\
\hline 12 & 84 & $\mathbf{P}$ & $57 \cdot 8$ & $1 \cdot 616$ & w & A & III \\
\hline Mean (men) & 78 & $\rightarrow$ & $65 \cdot 0$ & I. 629 & & & \\
\hline \multicolumn{8}{|l|}{ Women } \\
\hline 13 & 73 & - & $74 \cdot 2$ & 1.533 & W & A & III \\
\hline 14 & 78 & 一 & $5 \mathrm{I} \cdot 2$ & $\mathrm{I} \cdot 580$ & $\mathbf{M}$ & $\mathrm{Sp}$ & III A \\
\hline 15 & 74 & - & $45 \cdot 2$ & I. 530 & M & Sp & III \\
\hline 16 & 81 & - & $50 \cdot 1$ & I.499 & W & A & III \\
\hline 17 & 76 & - & 68.6 & $\mathrm{I} \cdot 576$ & $\mathbf{M}$ & $\mathrm{Sp}$ & $\mathrm{V}$ \\
\hline 18 & 84 & - & $52 \cdot 5$ & 1.480 & W & $\mathrm{R}$ & III \\
\hline 19 & 73 & 一 & $59 \cdot 7$ & I. 489 & M & $\mathrm{Sp}$ & $\mathrm{V}$ \\
\hline 20 & 80 & 一 & $59 \cdot 4$ & 1.590 & $\mathrm{~S}$ & $\mathrm{~F}$ & IV \\
\hline 21 & 78 & - & 62.8 & $\mathrm{I} \cdot 548$ & W & A & III \\
\hline 22 & 79 & 一 & 65.5 & 1.455 & W & A & III A \\
\hline 23 & 76 & 一 & $72 \cdot 0$ & $1 \cdot 409$ & W & A & III \\
\hline Mean (women) & 77 & & $60 \cdot 1$ & $I \cdot 517$ & & & \\
\hline $\begin{array}{r}\text { Mean (all } \\
\text { subjects) }\end{array}$ & $77 \cdot 5$ & & $61 \cdot 4$ & $I \cdot 575$ & & & \\
\hline
\end{tabular}

\section{Clinical}

Each subject saw the same clinician at each of their six visits, a full clinical examination being carried out on each occasion. Particular attention was paid both to the recording and standardization of signs and symptoms possibly associated with deficiency of vitamin $\mathrm{C}$ and riboflavin.

\section{Biochemical}

At each clinic visit, $30 \mathrm{ml}$ heparinized blood were obtained from each subject by venepuncture. A portion of the sample $(4 \mathrm{ml})$ was used for routine haematology, $6 \mathrm{ml}$ for routine biochemical tests, and the remaining $20 \mathrm{ml}$ for the vitamin status tests. Of the $20 \mathrm{ml}$ sample $8 \mathrm{ml}$ were centrifuged at $4^{\circ}$ to separate plasma (used for plasma vitamin $\mathrm{C}$, folic acid, 25-hydroxycholecalciferol and cholesterol measurements) and the buffy coat was removed from the erythrocyte layer and discarded.

The erythrocyte pellets, after washing with saline ( $9 \mathrm{~g}$ sodium chloride/l) and storage at $-25^{\circ}$ for a few days were used for the $\mathrm{NAD}(\mathrm{P}) \mathrm{H}_{2}$ : glutathione oxidoreductase (glutathione reductase; $E C$ I.6.4.2) assay for riboflavin status (based on Glatzle et al. 1970). After thawing, the pellets were haemolysed in 10 vol. ice-cold water for $45 \mathrm{~min}$, centrifuged, and the supernatant fractions diluted roo-fold in buffer, $\mathrm{pH} 7 \cdot 4$, containing sodium phosphate, 
$0.1 \mathrm{~mol} / 1$ and EDTA $2.5 \mathrm{mmol} / \mathrm{l}$. Four cuvettes each containing the same haemolysate were incubated at $30^{\circ}$ in a recording spectrophotometer operating cyclically; two of the cuvettes also contained FAD, final concentration $8.2 \mu \mathrm{mol} / \mathrm{l}$. Oxidized glutathione, final concentration $0.9 \mathrm{mmol} / \mathrm{l}$ was then added, and after a pre-incubation period of $4.7 \mathrm{~min}$, the reaction was initiated with $\mathrm{NADPH}$, final concentration $0.08 \mathrm{mmol} / \mathrm{l}$. Full-scale deflexion was 0.4 extinction units, and the linear slope between 4.7 and I I min after the final addition was used for the calculation of reaction rate in each cuvette.

The activation coefficient ( $\alpha$; stimulated:basal activity) is the currently-accepted index of riboflavin status.

\section{Dietary}

Each subject was asked to keep a daily qualitative record (menu) of all food and drink consumed for one whole year, i.e. slightly less than the period spanned by clinical examinations. The subjects were retired and many were living alone. They therefore enjoyed visits by the field workers, and the task of recording for such a long time was quite acceptable. Virtually continuous records, except for the Christmas and annual holiday periods, were obtained from all subjects except one (subject no. 3). The field workers checked the records weekly with the subjects and any omissions or discrepancies were rectified. Occasional snacks may have been missed, and beer was possibly under-recorded by one man, but otherwise the records appeared to be entirely satisfactory. The menu records were used to obtain the total frequency of consumption of different foods over given periods of time.

In addition to these essentially qualitative records most of the subjects weighed one or more complete days of food intake at intervals of approximately 6-8 weeks, and at the end of the main study period one complete week's food intake was weighed for nineteen of the twenty-three subjects. For nine subjects the field workers did some or all of the weighing; the other twelve weighed their food themselves, after careful instruction, and with frequent visits being made by the field workers during the week. Weighed intake information was obtained from five subjects for more than $19 \mathrm{~d}$ altogether; from ten subjects for $13-19 \mathrm{~d}$; from six subjects for 7-12 d and for only two subjects (subject nos. 3 and 15) was no weighed food intake information obtained. The weighed food intake information was used to derive, for each subject, characteristic portion sizes for the foods most frequently consumed.

The mean daily riboflavin intake from major food sources was estimated from the frequency of consumption of specified foods (as defined later), the subjects' characteristic portion sizes, and the nutrient content as given in tables supplied by the DHSS (DHSS, unpublished results). Average portion sizes derived from the whole group (males and females separately) were used where information for the individual subject was lacking; this applied mainly to subjects nos. 3 and I5.

The foods included in the estimation of nutrient intake were: (a) the foods most frequently eaten (six or more times in any 12-week period between visits to the clinic); (b) all foods identified as having a high content of vitamin $\mathrm{C}$ or riboflavin per portion and; $(c)$ where necessary, extra foods in descending order of frequency of consumption to ensure that at least $70 \%$ of the total frequency for each food group was included.

In calculating riboflavin intakes the DHSS food composition tables (DHSS, unpublished results) were modified as follows. Samples of the types of beer and yoghurt consumed by the subjects were analysed by a standard microbiological method using Lactobacillus casei (Recommendations of the Subcommittee on Vitamin Estimation, I946). Losses of riboflavin in milk through exposure to light during and after delivery to the house were also assessed, but were considered to be negligible.

A record of vitamin supplements containing riboflavin was kept, and the contribution which they made to the mean daily intake was added to the dietary intake. 
The study was approved by the ethical committees of the Dunn Nutrition Unit, Sunderland Hospital and Sunderland Local Medical Association and the British Medical Association.

\section{RESULTS \\ Clinical}

At their initial clinical examination, twenty of the twenty-three subjects were still regarded as essentially healthy, despite evidence in nearly all of them of some extent of ischaemic heart disease, peripheral vascular disease or osteoarthritis. Of the three subjects whose life-style was restricted to some extent by their health, subject no. 2 I, a diabetic with congestive cardiac failure and subject no. I0, an osteoarthritic with poor sight remained quite stable, but subject no. I2, a partially-sighted chronic bronchitic with emphysema deteriorated somewhat during the study. Three other subjects (subject nos. 2, I I and I8) also became somewhat frail during the study. Six subjects had no recorded illness during the study; the remaining seventeen subjects had a total of thirty-eight episodes of minor infectious and other transient illness, nineteen involving the respiratory system, mostly during the winter months, and nine the digestive system.

The body-weight of seventeen subjects changed by less than $2.5 \mathrm{~kg}$ during the study period; on average there was a loss of $0.5 \mathrm{~kg} /$ year. Three subjects (nos. 5, 7 and 19) gained more than $2.5 \mathrm{~kg}$, and three subjects (nos. 2, 12, and I6) lost more than $2.5 \mathrm{~kg}$; in subjects nos. 2 and 12 this was associated with poorer general health.

Angular stomatitis and cheilosis was recorded in only one individual (subject no. 17) at the first visit; it was not seen thereafter, and was not associated with low intake or biochemical status of riboflavin or of the other vitamins studied. Geographical and raw inflamed tongues were not seen in any subjects during the study.

\section{Biochemical and haematological}

Routine haematological measurements included erythrocyte count, leucocyte count, haemoglobin, packed cell volume, mean cell haemoglobin concentration and mean cell volume. Mean values below the normal range were found for erythrocyte count in two subjects (nos. 3 and $15,3.5$ and $3.7 \times 10^{8} / \mathrm{mm}^{3}$ respectively), for haemoglobin in subject no. $3(10.5 \mathrm{~g} / \mathrm{dl})$ and for packed cell volume in subject nos. 3 and I I $(31.6$ and $36.5 \%$ respectively); subject no. 3 was treated for anaemia during the study. Routine biochemical measurements included plasma protein, albumin, calcium, inorganic phosphate, alkaline phosphatase (EC 3.I.3.I), urea, bilirubin and glucose. The means for most of these measurements were close to the mid-point of the normal range. The only instances of values outside the normal range were for glucose (subject nos. II, 13, 2I and 23; 107, I09, 274 and $108 \mathrm{mg} / \mathrm{dl}$ respectively), urea (subject no. $3 ; 52 \mathrm{mg} / \mathrm{dl}$ ) and bilirubin (subject no. $2 \mathrm{I} ; \mathrm{I} .6 \mathrm{mg} / \mathrm{dl}$ ); with the exception of glucose in the diabetic (subject no. 2I) none of these were grossly abnormal. Electrolyte values were normal in all subjects.

\section{Riboflavin status}

(a) Biochemical. The $\alpha$ value for erythrocyte glutathione reductase for each subject at each clinic, and the over-all mean values for each subject and for each clinic are shown in Table 2.

In general the values for each subject were fairly constant throughout the study, withinsubject variation being approximately one-quarter of between-subject variation. Eight 
Table 2. Individual and mean values for the activation coefficient ( $\alpha$; stimulated: basal activity) of erythrocyte $\mathrm{NAD}(P) \mathrm{H}_{2}$ :glutathione oxidoreductase $\left(E C \mathrm{I}_{1.6 .4 .2)}\right.$ in healthy elderly men and women

\begin{tabular}{|c|c|c|c|c|c|c|c|c|}
\hline \multirow{3}{*}{$\begin{array}{l}\text { Clinic no. }{ }^{*} \quad \ldots \\
\text { Period of study ... }\end{array}$} & \multicolumn{8}{|c|}{$\alpha$ for each clinic } \\
\hline & $\mathbf{I}$ & 2 & 3 & 4 & 5 & 6 & 7 & \\
\hline & $\begin{array}{l}\text { July- } \\
\text { Aug. }\end{array}$ & $\begin{array}{l}\text { Sept.- } \\
\text { Nov. }\end{array}$ & $\begin{array}{l}\text { Dec.- } \\
\text { Feb. }\end{array}$ & $\begin{array}{l}\text { Mar.- } \\
\text { May }\end{array}$ & $\begin{array}{l}\text { June- } \\
\text { July }\end{array}$ & $\begin{array}{l}\text { Aug.- } \\
\text { Oct. }\end{array}$ & $\begin{array}{l}\text { Nov.- } \\
\text { Dec. }\end{array}$ & $\begin{array}{l}\text { Mean for } \\
\text { all six }\end{array}$ \\
\hline Subject no. & 1975 & 1975 & $1975 / 6$ & 1976 & 1976 & 1976 & 1976 & clinics \\
\hline \multicolumn{9}{|l|}{ Men } \\
\hline $\mathbf{I}$ & I $\cdot 27$ & $I \cdot 17$ & $I \cdot 24$ & $I \cdot 23$ & $I \cdot 19$ & $I \cdot I I$ & 一 & $1 \cdot 20$ \\
\hline 2 & $I \cdot 36$ & $I \cdot 35$ & $1 \cdot 3 I$ & $x \cdot 37$ & $I \cdot 30$ & $I \cdot 23$ & 一 & $1 \cdot 33$ \\
\hline 3 & $1 \cdot 28$ & I 26 & $1 \cdot 30$ & 1.07 & $I \cdot 2 I$ & $I \cdot 19$ & - & $1 \cdot 22$ \\
\hline 4 & $I \cdot 20$ & $I \cdot 20$ & $1 \cdot 08$ & I $\cdot 07$ & $I \cdot I 2$ & I.I I & 一 & $1 \cdot 13$ \\
\hline 5 & $1 \cdot 30$ & $1 \cdot 28$ & $\mathrm{I} \cdot 06$ & $I \cdot 22$ & $I \cdot 13$ & $I \cdot I 4$ & - & $I \cdot 19$ \\
\hline 6 & $1 \cdot 20$ & $I \cdot I 4$ & $1 \cdot 08$ & $I \cdot I I$ & 1.08 & $1 \cdot 13$ & - & $I \cdot 12$ \\
\hline 7 & $\mathrm{I} \cdot 44$ & $1 \cdot 26$ & $1 \cdot 18$ & $\mathrm{I} \cdot 25$ & $I \cdot I 3$ & $1 \cdot 33$ & - & $1 \cdot 26$ \\
\hline 8 & $1 \cdot 17$ & $I \cdot 15$ & $\mathrm{I} \cdot \mathrm{IO}$ & $1 \cdot 11$ & $1 \cdot 06$ & $I \cdot I I$ & 一 & $1 \cdot 12$ \\
\hline 9 & $I \cdot 34$ & $1 \cdot 27$ & $I \cdot 28$ & $I \cdot 24$ & I. Id & $I \cdot 20$ & - & $1 \cdot 25$ \\
\hline IO & $I \cdot 4 I$ & $1 \cdot 43$ & $1 \cdot 35$ & I 34 & $1 \cdot 20$ & $I \cdot 40$ & 一 & $1 \cdot 35$ \\
\hline I I & $1 \cdot 57$ & $1 \cdot 53$ & $I \cdot 44$ & $I \cdot 44$ & $1 \cdot 36$ & $1 \cdot 32$ & - & $I \cdot 44$ \\
\hline 12 & I.04 & 1.02 & 1.06 & 1.02 & $1 \cdot 00$ & 1.00 & - & I.02 \\
\hline Mean & $1 \cdot 30$ & $1 \cdot 25$ & $I \cdot 2 I$ & $I \cdot 2 I$ & $I \cdot 16$ & $1 \cdot 19$ & - & $I \cdot 22$ \\
\hline \multicolumn{9}{|l|}{ Women } \\
\hline I 3 & $1 \cdot 20$ & $I \cdot 2 I$ & $I \cdot 22$ & $1 \cdot 25$ & $I \cdot 19$ & $1 \cdot 15$ & 一 & $1 \cdot 20$ \\
\hline I4 & $1 \cdot 25$ & $I \cdot 2 I$ & $I \cdot 22$ & $I \cdot I I$ & 1.07 & $1 \cdot 17$ & - & $\mathrm{I} \cdot 17$ \\
\hline I5 & $1 \cdot 17$ & $1 \cdot 32$ & $I \cdot 29$ & $I \cdot 36$ & $I \cdot 16$ & $1 \cdot 30$ & - & $1 \cdot 27$ \\
\hline 16 & $I \cdot 10$ & $1 \cdot 04$ & 1.05 & $I \cdot 06$ & $I \cdot O I$ & 1.07 & $\longrightarrow$ & 1.05 \\
\hline 17 & - & $1 \cdot 14$ & $I \cdot 26$ & I. II & $I \cdot 13$ & $1 \cdot 10$ & 1.07 & $1 \cdot 13$ \\
\hline I8 & - & 1.02 & 1.04 & $\mathrm{I} \cdot 03$ & $1 . \infty$ & 1.02 & 0.97 & I.OI \\
\hline 19 & $I \cdot 43$ & $I \cdot 2 I$ & $1 \cdot 33$ & $1 \cdot 23$ & $I \cdot 24$ & $1 \cdot 25$ & - & $\mathrm{I} \cdot 28$ \\
\hline 20 & - & $I \cdot 14$ & $1 \cdot 17$ & $1 \cdot 17$ & 1.06 & $I \cdot 15$ & 1.06 & $I \cdot 12$ \\
\hline $2 \mathrm{I}$ & $I \cdot I 4$ & $1 \cdot 20$ & $I \cdot 15$ & $I \cdot 15$ & 116 & I 13 & - & $1 \cdot 15$ \\
\hline 22 & - & $1 \cdot 16$ & $I \cdot 15$ & I.II & 1.03 & $1 \cdot 13$ & $1 \cdot 13$ & $I \cdot 12$ \\
\hline 23 & $I \cdot 18$ & $1 \cdot 18$ & $1 \cdot 18$ & $1 \cdot 09$ & $1 \cdot 15$ & $1 \cdot 10$ & - & $1 \cdot 15$ \\
\hline Mean & - & $1 \cdot 17$ & $I \cdot I 9$ & $I \cdot 15$ & $I \cdot I I$ & $I \cdot 14$ & - & $I \cdot I 5$ \\
\hline $\begin{array}{l}\text { Mean (all } \\
\text { subjects) }\end{array}$ & - & $\mathrm{I} \cdot 2 \mathrm{I}$ & $I \cdot 20$ & $1 \cdot 18$ & $I \cdot 14$ & $I \cdot I 7$ & - & $1 \cdot 19$ \\
\hline
\end{tabular}

* Clinics were held at intervals of 4 weeks, eight individuals being seen at each clinic.

subjects had mean $\alpha$ values greater than I.2. $\alpha$ values were significantly lower $(P<0.00 \mathrm{I}$, paired $t$ test) during June-July 1976 than during December-February 1975-6; however there was no corresponding difference between July-August, 1975 and December-February, 1975-6.

A strong negative correlation was found between mean values of $\alpha$ and of the basal glutathione reductase activity within subjects $(r-0.7 \mathrm{I}, P<0.00 \mathrm{I})$ and between subjects $(r-0.88, P<0.001)$. There was also a strong negative between-subject correlation between $\alpha$ and stimulated glutathione reductase activity $(r-0.71, P<0.001)$.

(b) Dietary. The mean ( \pm SD) riboflavin intake (Table 3 ) from major food sources estimated over all completed weeks of the survey was $I \cdot 2 \pm 0.2 \mathrm{mg} / \mathrm{d}$ with a range of $0.6-$ $\mathrm{I} \cdot 8 \mathrm{mg} / \mathrm{d}$ between subjects. On the days when total food intake was recorded by weighing, the remaining foods not included as major food sources contributed approximately a further $0.3 \mathrm{mg}$ riboflavin/d. Two subjects (nos. I 2 and I 8 ) took regular supplements which considerably enhanced their riboflavin intake. The variation from week to week was relatively small in most subjects, as the standard deviation was $0.2 \mathrm{mg}$ or less in sixteen of the 
Table 3. Mean daily intake $(\mathrm{mg} / \mathrm{d})$ of riboflavin from major food sources of healthy elderly men and women

Riboflavin intake $\uparrow$ for the week before each clinic

\begin{tabular}{|c|c|c|c|c|c|c|c|c|c|}
\hline \multirow[b]{2}{*}{ Clinic no. ${ }^{*} .}$. & \multicolumn{5}{|c|}{ each clinic } & \multicolumn{4}{|c|}{$\begin{array}{l}\text { Riboflavin intake } \ddagger \text { for all complete } \\
\text { weeks of dietary assessment }\end{array}$} \\
\hline & 2 & 3 & 4 & 5 & 6 & & & & \\
\hline $\begin{array}{l}\text { Subject no. } \\
\text { Men }\end{array}$ & & & & & & Mean & $\mathrm{SD}$ & $\mathrm{CV}$ & $\begin{array}{l}\text { No. of } \\
\text { weeks }\end{array}$ \\
\hline $\mathbf{I}$ & $I \cdot 4$ & $1 \cdot 2$ & $1 \cdot 3$ & $I \cdot 3$ & $I \cdot 2$ & $I \cdot 3$ & $0 . I$ & 8 & 53 \\
\hline 2 & $\mathrm{I} \cdot 4$ & $I \cdot 2$ & $\mathbf{I} \cdot \mathbf{I}$ & $1 \cdot 0$ & - & $1 \cdot 2$ & 0.2 & 17 & 51 \\
\hline 3 & $I \cdot 4$ & - & $1 \cdot 7 \dagger$ & 0.8 & - & $1 \cdot 2$ & 0.4 & 33 & 17 \\
\hline 4 & $I \cdot I$ & 0.9 & $I \cdot 3$ & $1 \cdot 0$ & - & $I \cdot I$ & 0.2 & 18 & 48 \\
\hline 5 & 0.9 & $2.0 t$ & 0.8 & $I \cdot I$ & - & $I \cdot 0$ & 0.2 & 20 & $5 I$ \\
\hline 6 & $2 \cdot 0$ & $2 \cdot 7$ & $1 \cdot 8$ & $1 \cdot 7$ & - & $1 \cdot 7$ & 0.1 & 6 & 46 \\
\hline 7 & $I \cdot I$ & $I \cdot 6$ & $\mathbf{I} \cdot \mathbf{I}$ & $1 \cdot 2$ & - & $1 \cdot 3$ & 0.3 & 23 & 55 \\
\hline 8 & $\mathrm{I} \cdot 5$ & $1 \cdot 6$ & $I \cdot 4$ & $I \cdot 4$ & $I \cdot I$ & $1 \cdot 5$ & 0.3 & 20 & 52 \\
\hline 9 & $1 \cdot 4$ & $1 \cdot 5$ & $1 \cdot 6$ & $1 \cdot 8$ & - & I' 5 & 0.3 & 20 & 51 \\
\hline I0 & $1 \cdot 3$ & $I \cdot 4$ & $I \cdot 6$ & $I \cdot 5$ & - & $I \cdot 6$ & 0.3 & 19 & 47 \\
\hline 11 & 0.6 & 0.5 & 0.7 & 0.6 & - & 0.6 & 0.1 & 17 & 50 \\
\hline I 2 & $4.3 \dagger$ & $4.2 \dagger$ & $4.4 \dagger$ & $4.2 \dagger$ & - & $I \cdot 2$ & 0.2 & 17 & 46 \\
\hline Mean & $1 \cdot 5$ & $1 \cdot 5$ & $1 \cdot 6$ & $1 \cdot 5$ & - & $I \cdot 2$ & 0.3 & 18 & 47 \\
\hline \multicolumn{10}{|l|}{ Women } \\
\hline 13 & $I \cdot 3$ & $I \cdot I$ & $1 \cdot 7$ & $1 \cdot 3$ & - & $1 \cdot 3$ & 0.2 & 15 & 51 \\
\hline 14 & 0.7 & 0.7 & 0.5 & $1 \cdot 2$ & - & 0.8 & 0.2 & 25 & 45 \\
\hline 15 & $I \cdot 4$ & $1 \cdot 5$ & - & $I \cdot I$ & - & 1.6 & 0.5 & 31 & 36 \\
\hline 16 & $I \cdot 3$ & 10 & 0.9 & - & - & $I \cdot I$ & $0 . I$ & 9 & 38 \\
\hline 17 & - & 0.9 & $I \cdot I$ & 0.8 & 0.8 & 0.9 & 0.3 & 33 & 44 \\
\hline 18 & - & $2 \cdot 1 \dagger$ & $2 \cdot 1 \dagger$ & $2 \cdot I \dagger$ & $2 \cdot 1 \dagger$ & $1 \cdot 1$ & 0.1 & 9 & 49 \\
\hline 19 & $I \cdot 6$ & 0.7 & $\mathrm{r} \cdot 2$ & $1 \cdot 5$ & - & $I \cdot I$ & 0.2 & 18 & 50 \\
\hline 20 & - & 1.0 & $I \cdot I$ & 0.7 & 0.9 & 0.9 & 0.2 & 22 & 44 \\
\hline 21 & $I \cdot I$ & $I \cdot I$ & $I \cdot 0$ & $I \cdot 0$ & - & $I \cdot I$ & 0.1 & 9 & 42 \\
\hline 22 & - & 0.8 & 0.7 & 0.7 & 0.8 & 0.8 & 0.1 & 13 & 47 \\
\hline 23 & 0.8 & 0.6 & 0.4 & 0.6 & 0.7 & 0.7 & 0.2 & 28 & 47 \\
\hline Mean & $I \cdot 2$ & $1 \cdot 0$ & $I \cdot I$ & $I \cdot I$ & - & I.O & 0.2 & $2 I$ & 45 \\
\hline $\begin{array}{l}\text { Mean } \\
\text { (all subjects) }\end{array}$ & $I \cdot 4$ & $1 \cdot 3$ & $x \cdot 3$ & $1 \cdot 3$ & - & $I \cdot 2$ & 0.2 & 20 & 46 \\
\hline
\end{tabular}

* Clinics were held at intervals of 4 weeks, eight individuals being seen at each clinic.

$\dagger$ Including supplements: subjects nos. 12 and 18 received supplements of 3.0 and $1 \cdot 0 \mathrm{mg} / \mathrm{d}$ respectively throughout the study; subjects nos. $3,5,13$ and 19 received occasional supplements, contributing $0.2,0.1$, 0.1 and $0.3 \mathrm{mg} / \mathrm{d}$ respectively over the whole study.

$\ddagger$ Excluding supplements.

twenty-three subjects. Where the standard deviation was greater, the individuals concerned either drank beer or ate liver regularly, and the distribution of their riboflavin week-byweek was positively skewed.

The riboflavin intake over differing periods of time in relation to the taking of the blood sample was compared, and the correlations with $\alpha$ are shown in Table 4. Clearly the correlations between subjects were little affected by the duration of the dietary assessment, but the correlations within subjects were more sensitive. Within-subject correlations, which are all significant and similar $(P<0.05)$, were obtained with dietary intake estimated over I d, $3 \mathrm{~d}, 7 \mathrm{~d}$ or 4 weeks immediately preceding the biochemical measurements. In contrast, dietary intake estimated over the I2-week period before the biochemical measurement, or the second week after it, failed to yield significant within-subject correlations. (The second week after the clinic was chosen to represent the situation which might occur in crosssectional studies where the clinical examination precedes the dietary records.) 
Table 4. Within- and between-subject correlations between riboflavin intake* and activation coefficient $\left(\alpha ;\right.$ stimulated:basal activity) of erythrocyte $\mathrm{NAD}(P) \mathrm{H}_{2}:$ glutathione oxidoreductase (EC I.6.4.2) in healthy elderly men and women

(Variation in df in the within-subject correlation is due to variation in nos. of time-points for which complete dietary information was available. The between-subject correlations represent the average of all available (3-5) time-points for each subject)

\begin{tabular}{|c|c|c|c|}
\hline $\begin{array}{l}\text { Source of } \\
\text { correlation }\end{array}$ & $\begin{array}{l}\text { Duration of } \\
\text { dietary assessment }\end{array}$ & $\mathrm{df}$ & $r$ \\
\hline $\begin{array}{l}\text { Within } \\
\text { subjects }\end{array}$ & $\begin{array}{l}\text { Day before each clinic } \\
3 \mathrm{~d} \text { before each clinic } \\
7 \mathrm{~d} \text { before each clinic } \\
4 \text { weeks before each clinic } \\
\text { I } 2 \text { weeks before each clinic } \\
\text { Second week after each clinic }\end{array}$ & $\begin{array}{l}67 \\
67 \\
69 \\
83 \\
90 \\
67\end{array}$ & $\begin{array}{l}-0.2 \\
-0.2 \\
-0.2 \\
-0.2 \\
-0.0 \\
-0.1\end{array}$ \\
\hline $\begin{array}{l}\text { Between } \\
\text { subjects }\end{array}$ & $\begin{array}{l}\text { Day before each clinic } \\
3 \mathrm{~d} \text { before each clinic } \\
7 \mathrm{~d} \text { before each clinic } \\
4 \text { weeks before each clinic } \\
\text { I } 2 \text { weeks before each clinic } \\
\text { Second week after each clinic }\end{array}$ & $\begin{array}{l}22 \\
22 \\
22 \\
22 \\
22 \\
22\end{array}$ & $\begin{array}{l}-0.3 \\
-0.3 \\
-0.4 \\
-0.3 \\
-0.3 \\
-0.3\end{array}$ \\
\hline
\end{tabular}

Statistical significance:

$-0.28 \quad 0.02 \dagger$

$-0.25<0.05$

$-0.28 \quad 0.02 \dagger$

$-0.25 \quad 0.02+$

$-0.04 \quad N S$

$-0.19 \quad$ NS

$-0.39 \quad$ NS

$-0.33 \quad$ NS

$-0.40 \quad 0.05 \dagger$

$-0.39 \quad$ NS

$-0.36 \quad$ NS

$-0.38 \quad$ NS

* From major food sources, including riboflavin supplements.

$\uparrow$ Approximate values.

Over the whole study, the between-subject correlation between riboflavin intake from major food sources and supplements and mean $\alpha$ value for erythrocyte glutathione reductase (Fig. I) was negative as expected $(r-0.37)$, but it did not reach significance $(0 . \mathrm{I}>P>0.05)$. The correlation was not improved by expressing intake per $\mathrm{kg}$ bodyweight; expressing intake per unit of energy intake resulted in a slight improvement $(r-0.44, P<0.05)$, but if the two supplemented subjects (nos. 12 and 18$)$ were omitted from the calculation, the correlation coefficient approached zero $(r+0.07)$. The correlation

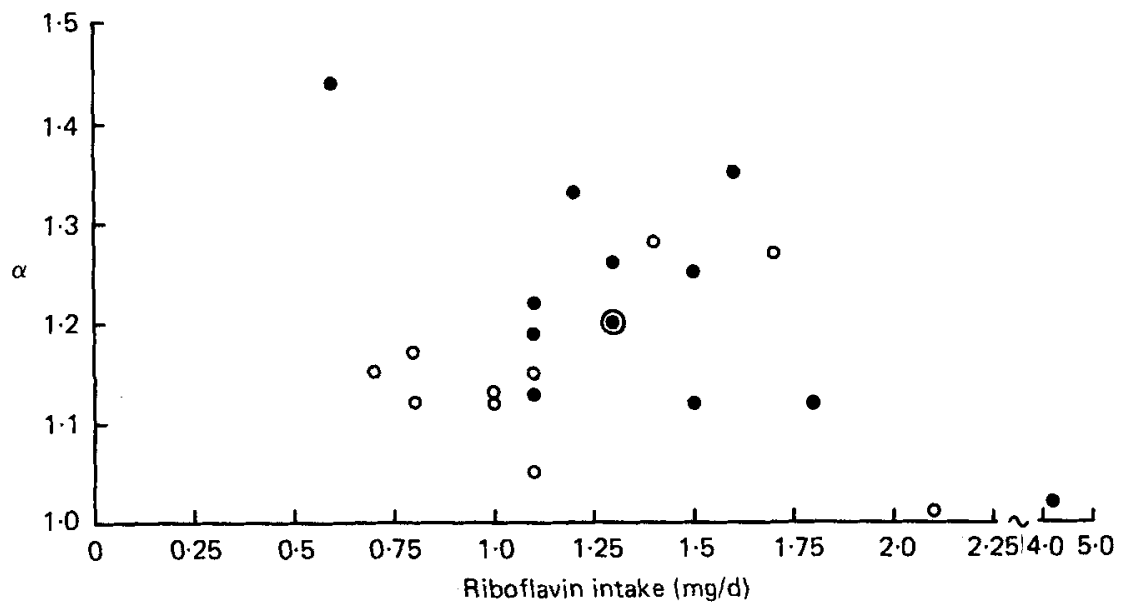

Fig. r. Relation of mean riboflavin intake ( $\mathrm{mg} / \mathrm{d}$ ), based on all available days of dietary informa* tion, to mean activation coefficient ( $\alpha$; stimulated :basal activity) $\mathrm{NAD}(\mathrm{P}) \mathrm{H}_{2}$ : glutathione oxidoreductase $(E C$ I 6.4 .2$)$ in healthy elderly men and women. (๑), Men; $(O)$, women. 
between intake and basal glutathione reductase activity was similar to that between intake and $\alpha$.

\section{DISCUSSION}

The strong between-subject correlation between basal activities of erythrocyte glutathione reductase and $\alpha$ values in our study, which has also been noted in younger subjects (Glatzle et al. 1974), implies that the extent of saturation with coenzyme is a major factor determining the basal activity for each individual. The correlation between stimulated activity and $\alpha$ appears stronger in our study than in that of Glatzle et al. (1974) and suggests that maximum potential activity was not achieved by in vitro addition of FAD to the depleted haemolysates. Whether this is due to loss of apoenzyme during long periods of continuous desaturation in vivo, or to incomplete reactivation in vitro (Staal et al. 1961; Garry \& Owen, 1976) is at present uncertain.

In all cross-sectional studies, the question arises whether single measurements are representative. The fact that most subjects had remarkably constant $\alpha$ values over I 8 months suggests that single measurements of $\alpha$ are reliable indicators of long-term biochemical status. This is reinforced by finding a strong positive correlation between the mean $\alpha$ values in this study and the single $\alpha$ values for the same subjects in the DHSS (DHSS, 1979) 1972-3 survey $(r+0.64, P<0.001)$.

The relative constancy of dietary intake indicates, similarly, that for riboflavin a single week's dietary record would provide a reasonable estimate of an individual's characteristic intake, as judged by the small standard deviation (less than $0.2 \mathrm{mg}$ ) or coefficient of variation (less than $20 \%$ ) in nineteen of the twenty-three subjects. This is reinforced by a highly significant correlation $(r+0.7 \mathrm{I}, P<0.001)$ found between the $7 \mathrm{~d}$ weighed records and the intake estimated over the whole period of study.

That there is a relationship between biochemical status and dietary intake is clearly indicated by the significant within-subject correlations obtained between the biochemical measurements and the intake over short periods of time directly preceding the biochemical measurement (Table 4). However, for longer periods of time, or for periods of dietary assessment unrelated to the time of biochemical measurement, no such correlations are obtained. There is also a significant between-subject correlation, and although the period of dietary assessment appears to be less critical, the best correlation (the only significant one) is obtained for I week's dietary assessment immediately preceding the biochemical measurement, which would therefore be the best method to adopt in cross-sectional studies. However it is often only practicable to measure dietary intake after subjects have been approached at a clinic, and in this situation a poorer correlation is to be expected.

The relationship between dietary intake and $\alpha$ value is evidently not a close one, and is only demonstrated between subjects when the range of intakes is wide. In this study the correlation approached zero when two subjects with markedly higher intakes, due to supplements, were excluded. Our findings are consistent with those of several other studies. Where the range of dietary intakes was rather narrow, and similar to the unsupplemented intakes in the present study, either no significant correlation was observed between intake and $\alpha$ (Buzina et al. I97I ; Vir \& Love, 1977), or a weak negative correlation $(r 0.2-0.4)$ has reached significance by virtue of the larger number of subjects (Smithells et al. 1977; DHSS, I979). In one study reporting a much higher correlation coefficient (Beutler, I969), the range of intakes was much wider $(0 \cdot 67-3 \cdot 7 \mathrm{mg} / \mathrm{d})$.

In studies where riboflavin intake was experimentally controlled (Bamji, 1969; Tillotson $\&$ Baker, 1972), $\alpha$ responded predictably to changes in intake. However, the absolute value of $\alpha$ for a given intake varied considerably between individuals, which confirms the import- 
ance of non-dietary variables in controlling $\alpha$ values. In cross-sectional studies therefore, the effect of small diet-related variations may be swamped.

On the other hand, several studies, including the present one, have shown that $\alpha$ values can be brought close to I 0 by supplementation with relatively large amounts of riboflavin (Glatzle et al. 1970; Sauberlich et al. 1972; Rosenthal et al. 1973; Hoorn et al. 1975).

The clinical and functional significance of high $\alpha$ values in individuals is difficult to assess. The upper limit of the normal range in Glatzle's (1970) study was I 2 . Average values above $\mathrm{I} \cdot \mathbf{2}$ were seen in eight subjects in the present study, but were not associated with any detectable clinical signs of deficiency. However, the normal range of $\alpha$ values in elderly people is not yet established, and it will undoubtedly be influenced by variations in the technique of measurement.

First and foremost the authors wish to thank the subjects for their patient cooperation over such a long period. They are indebted to the nutrition field workers, Miss E. Allen and Mrs E. Muncaster, the nurse, Mrs K. Hodgson, the staff at the Sunderland General Hospital for help and outpatient facilities, and the staff at the Sunderland Royal Hospital for routine biochemical and haematological analyses. They also thank Mrs M. Fleming, Mrs C. Godfrey and Mrs B. Sutcliffe for technical assistance, Mr K. Day for computer analysis, and Dr R. G. Whitehead and Professor A. N. Exton-Smith for their encouragement and advice. Unpublished information from the 1967-8 and 1972-3 surveys was kindly made available to them by the Department of Health and Social Security.

\section{REFERENCES}

Bamji, M. S. (1969). Clinica chim. Acta 26, 263.

Bates, C. J., Rutishauser, I. H. E., Black, A. E., Paul, A. A., Mandal, A. R. \& Patnaik, B. K. (I979). Br. J. Nutr. 42, 43.

Beutler, E. (1969). J. clin. Invest. 48, 1957.

Brin, M., Schwartzberg, S. H. \& Arthur-Davis, D. (1964). J. Am. geriat. Soc. 12, 493.

Buzina, R., Jusic, M., Brodarec, A., Milanovic, N., Brubacher, G., Vuilleumier, J. P., Wiss, O. \& Christeller, S. (197I). Int. Z. VitamForsch. 4I, 289.

Department of Health and Social Security (1972). Rep. Hlth Soc. Subj. no. 3. London: H.M. Stationery Office.

Department of Health and Social Security (1979). Rep. Hlth Soc. Subj, no. 16. London: H.M. Stationery Office.

Exton-Smith, A. N. \& Stanton, B. R. (1965). Report on an Investigation into the Diet of Elderly Women Living Alone. London: King Edward's Hospital Fund.

Garry, P. J. \& Owen, G. M. (1976). Am. J. clin. Nutr. 29, 663.

Glatzle, D., Korner, W. F., Christeller, S. \& Wiss, O. (I970). Int. Z. VitamForsch. 40, 166.

Glatzle D., Vuilleumier, J. P., Weber, F. \& Decker, K. (1974), Experientia 30, 665.

Griffiths, L. L., Brocklehurst, J. C., Scott, D. L., Marks, J. \& Blackley, J. (1967). Geront. clin. 9, I.

Hoorn, R. K. J., Flikweert, J. P. \& Westerink, D. (1975). Clinica. chim. Acta 61, 151.

Recommendations of the Subcommittee on Vitamin Estimation (1946). Analyst, Lond. 7r, 397.

Rosenthal, W. S., Adham, N. F., Lopez, R. \& Cooperman, J. H. (1973). Am. J. clin. Nutr. $26,858$.

Sauberlich, H. E., Judd, J. H., Nichoalds, G. E., Broquist, H. P. \& Darby, W. J. (1972). Am. J. clin. Nutr 25, 756 .

Smithells, R. W., Ankers, C., Carver, M. E., Lennon, D., Schorah, C. J. \& Sheppard, S. (1977). Br. J. Nutr. 38, 497.

Staal, G. E. J., Visser, J. \& Veeger, C. (196I). Biochim. biophys. Acta $\mathbf{1 8 5}, 39$.

Stanton, B. R. \& Exton-Smith, A. N. (I970). A Longitudinal Study of the Diet of Elderly Women. London: King Edward's Hospital Fund.

Tillotson, J. S. \& Baker, E. M. (1972). Am. J. clin. Nutr. 25, 425.

Vir, S. C. \& Love, A. H. G. (1977). Int. Z. VitamForsch. 47, 336. 